\title{
LATE GLACIAL AND HOLOCENE VEGETATION CHANGES IN THE WIGRY NATIONAL PARK, NE POLAND - NEW POLLEN DATA FROM THREE SMALL DYSTROPHIC LAKES
}

\author{
Magdalena Fiłoc, Mirosława Kupryjanowicz, Danuta Drzymulska \\ Department of Botany, Institute of Biology, University of Biatystok, Świerkowa 20b, 15-950 Biatystok, Poland; \\ e-mail:mfiloc@op.pl,m.kupryjanowicz@uwb.edu.pl,drzym@uwb.edu.pl
}

\begin{abstract}
The main phases of the Late Glacial and Holocene development of vegetation in the Wigry National Park were reconstructed based on the pollen analysis of sediments from three small dystrophic lakes (Lake Suchar Wielki, Lake Suchar II and Lake Ślepe). At the current stage of research, the age of the studied deposits was determined by AMS radiocarbon dating of few samples only. This meant that the chronology of the investigated profiles had to be estimated also indirectly using their palynological correlation with a radiometrically well-dated profile from Lake Wigry. The obtained pollen data confirmed the picture of the postglacial vegetation changes of the Wigry National Park, which was based on earlier studies of Lake Wigry. Furthermore, it documented the existence, mainly in the Preboreal and Atlantic chronozones, of temporary changes in vegetation, which might be a reaction to a short-lived cold fluctuations of climate.
\end{abstract}

Key words: postglacial succession of vegetation, palaeoecological reconstruction, climate changes, Late Glacial, Holocene, pollen analysis, Wigry National Park, NE Poland

Manuscript received 5 September 2013, accepted 6 May 2014

\section{INTRODUCTION}

The degree of knowledge on postglacial vegetation development in the Suwałki region, as for the entire north-eastern Poland, is still not satisfactory (Ralska-Jasiewiczowa et al., 2004, Kupryjanowicz 2008). The palaeobotanical research in this area started in the first half of the $20^{\text {th }}$ century (Osinki I and II, Krzywe, Suchar Dembowskich, Zakaty Ołtuszewski 1937), and then continued in the second half of this century (Krusznik - Stasiak 1971), however, from the point of view of contemporary standards of palaeoecological researches, all of these studies are only of historical value. Solely the results of recent palaeobotanical studies conducted in the last decade, which have been supported by many additional palaeoecological analyzes, can be used to carry out the modern palaeoecological reconstructions (Lake Wigry - Kupryjanowicz 2007, Kupryjanowicz and Jurochnik 2009, Rutkowski and Krzysztofiak 2009; Lake HańczaLauterbach et al., 2010; Lake Szurpiły - Tylmann et al., 2011; Lake Linówek - Gałka and Tobolski 2013). Even these, however, do not provide a complete picture of the changes. The profile from Lake Wigry - the largest water body in the Wigry National Park, while it allowed to reconstruct the main stages of postglacial succession of vegetation in the region (Kupryjanowicz 2007), yet for the Late Glacial and Early Holocene provided a very low resolution of the record of environmental changes (every 200-300 years). In the profile from Lake Szurpiły, the biogenic sedimentation was interrupted at the beginning of the Atlantic period by the accumulation of a thick (about $1 \mathrm{~m}$ ) layer of sand not containing pollen (Tylmann et al., 2011). In the profile from Lake Hańcza there is a sedimentation hiatus, covering almost whole the middle Holocene (Lauterbach et al., 2010). Therefore, further studies are needed to complement the existing deficiencies.

From few years the Department of Botany at the University of Bialystok has been conducting an interdisciplinary palaeoecological research of several dystrophic lakes located within the Wigry National Park (Drzymulska and Kupryjanowicz 2012, Drzymulska 2012, Drzymulska et al., 2013a, b, c, Fiłoc 2013a, b, Fiłoc and Kupryjanowicz 2013a, b). The study includes a lot of aspects of the history of the examined lakes. A part of the project is a pollen analysis of sediments from three water bodies - Lake Ślepe, Lake Suchar Wielki and Lake Suchar II. Its main purpose is to reconstruct the vegetation changes both around and within studied water bodies under the influence of the climate changes that have been taking place over the last ca. 12 thousand years. In this paper we presented the preliminary results of these studies, which made it possible to reconstruct the main stages of vegetation development in the Wigry National Park during the Late Glacial of Vistulian and the Holocene. These data were confronted with the prior knowledge of the post glacial vegetation development in the Suwałki region. 


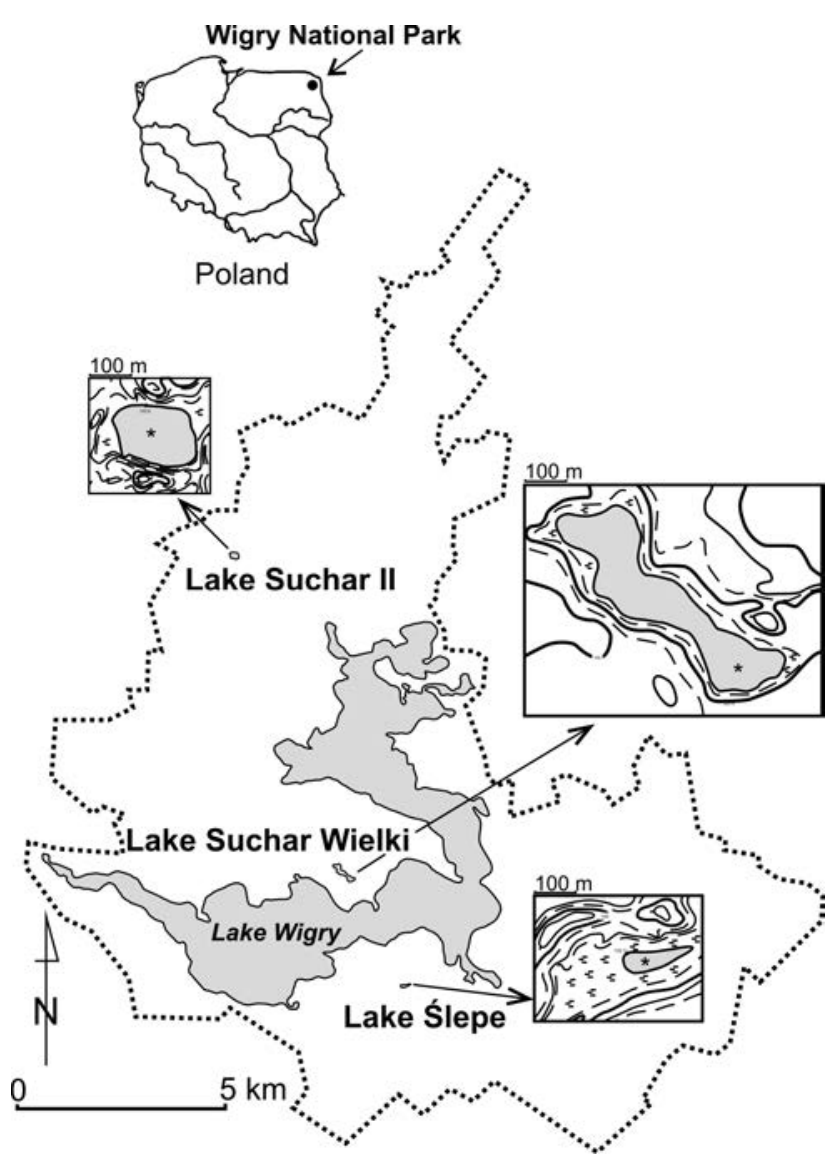

Fig. 1. Location of studied lakes. ${ }^{*}$ - places of the corings.

\section{STUDY AREA}

Lake Ślepe (LS), Lake Suchar II (LSII), and Lake Suchar Wielki (LSW) are located in the Wigry National Park (WNP), north-eastern Poland (Fig. 1). The two physical-geographical mesoregions, the East Suwałki Lakeland and the Augustów Upland, occur in this part of Poland, and both are included in the Lithuanian Lakeland (Kondracki 1994). The terrain of this area was shaped during the Pomeranian phase of the main stadial of the Vistula Glaciation (Marks 2002). The climate of this area is temperate transitional with a tendency toward continental. This area is characterized by the most severe climatic conditions across the lowland parts of the country (Krzysztofiak and Olszewski 1999). Not far from the Wigry National Park there are the range limits of many plant species, mainly trees (e.g. Picea abies, Taxus baccata, Acer pseudoplatanus, Quercus sessilis, Fagus sylvatica), shrubs (e.g. Salix lapponum) and dwarf shrubs (e.g. Rubus chamaemorus) (Szafer and Zarzycki 1977). These all plants occur here on the border of their ecological tolerance.

\section{METHODS}

\section{Fieldworks}

The drilling in deep spots of all the lakes was carried out using the Więckowski's probe with a length of $110 \mathrm{~cm}$ and a diameter of $5 \mathrm{~cm}$. Cores of bottom sediments with the thickness of $9.60 \mathrm{~m}$ (Lake Suchar Wielki), $5.95 \mathrm{~m}$ (Lake Suchar II) and $5.18 \mathrm{~m}$ (Lake Ślepe) were collected. It was necessary
Table 1

Radiocarbon dating of the analyzed sediments.

\begin{tabular}{|c|c|c|c|c|c|}
\hline \multirow{2}{*}{ Core } & $\begin{array}{c}\text { Depth } \\
{[\mathrm{m}]}\end{array}$ & $\begin{array}{c}\text { Dated } \\
\text { material }\end{array}$ & $\begin{array}{c}\text { Age }{ }^{14} \mathrm{C} \\
(\mathrm{yrs} B P\end{array}$ & \multicolumn{2}{|c|}{ Calibrated age (cal.yrs BP) } \\
\cline { 5 - 6 } & range 68.2\% & range $95.4 \%$ \\
\hline SW & 10.42 & plant remains & $3,170 \pm 25$ & $3,443-3,404$ & $3,449-3,359$ \\
\hline SW & 13.82 & sediment & $7,820 \pm 35$ & $8,629-8,560$ & $8,704-8,521$ \\
\hline SW & 15.02 & plant remains & $8,560 \pm 50$ & $9,550-9,495$ & $9,627-9,470$ \\
\hline SW & 15.74 & sediment & $9,640 \pm 45$ & $11,172-10,827$ & $11,189-10,785$ \\
\hline SII & 12.17 & sediment & $10,120 \pm 30$ & $11,916-11,626$ & $11,987-11,508$ \\
\hline
\end{tabular}

SW - Lake Suchar Wielki, SII - Lake Suchar II

Table 2

Lithology of analyzed profiles. Depths are counted from the water surface

\begin{tabular}{|c|c|}
\hline Depth $[\mathrm{m}]$ & Sediment description \\
\hline \multicolumn{2}{|c|}{ Lake Suchar Wielki } \\
\hline $7.57-16.74$ & dy \\
\hline $16.74-16.77$ & sand with shells \\
\hline $16.77-16.80$ & fine-detritus gyttja \\
\hline $16.80-16.86$ & sand with shells \\
\hline $16.86-16.94$ & calcareous gyttja \\
\hline $16.94-17.06$ & clay with sand \\
\hline \multicolumn{2}{|c|}{ Lake Suchar II } \\
\hline $6.50-12.20$ & dy \\
\hline $12.20-12.32$ & silt \\
\hline $12.32-12.42$ & peat-like sediment \\
\hline $12.42-12.51$ & sand with shells and gravel \\
\hline $12.51-12.55$ & silt \\
\hline $12.55-12.60$ & sand with shells and gravel \\
\hline \multicolumn{2}{|c|}{ Lake Ślepe } \\
\hline $0.75-5.73$ & dy \\
\hline $5.73-5.80$ & silt \\
\hline $5.80-6.23$ & sand with shells and gravel \\
\hline $6.23-6.40$ & gravel \\
\hline
\end{tabular}

to supplement the collected profiles with top layers of highly liquefied sediments that could not be collected with a Więckowski's probe. The missing sediments from Lake Suchar Wielki $-0.50 \mathrm{~m}$ and from Lake Ślepe $-0.23 \mathrm{~m}$ were collected using the Kajak probe. The sediments from Lake Suchar II were not collected yet.

\section{Age of sediments}

The age of the 4 samples of sediments from Lake Suchar Wielki and 1 sample of sediments from Lake Suchar II was determined by AMS radiocarbon method (Tab. 1). OxCal 4.2.3 online software (Bronk Ramsey 2009) was used to calibrate the radiocarbon age of the samples. Due to a very small number of radiocarbon age determinations in the studied profiles, the chronology of events recorded in these profiles has been determined also indirectly, based on a similarity between pollen spectra with the radiometrically well-dated profile from the nearby Lake Wigry (Kupryjanowicz 2007). The age of the sediments determined thus was compared with AMS radiocarbon dating (Fig. 2). 


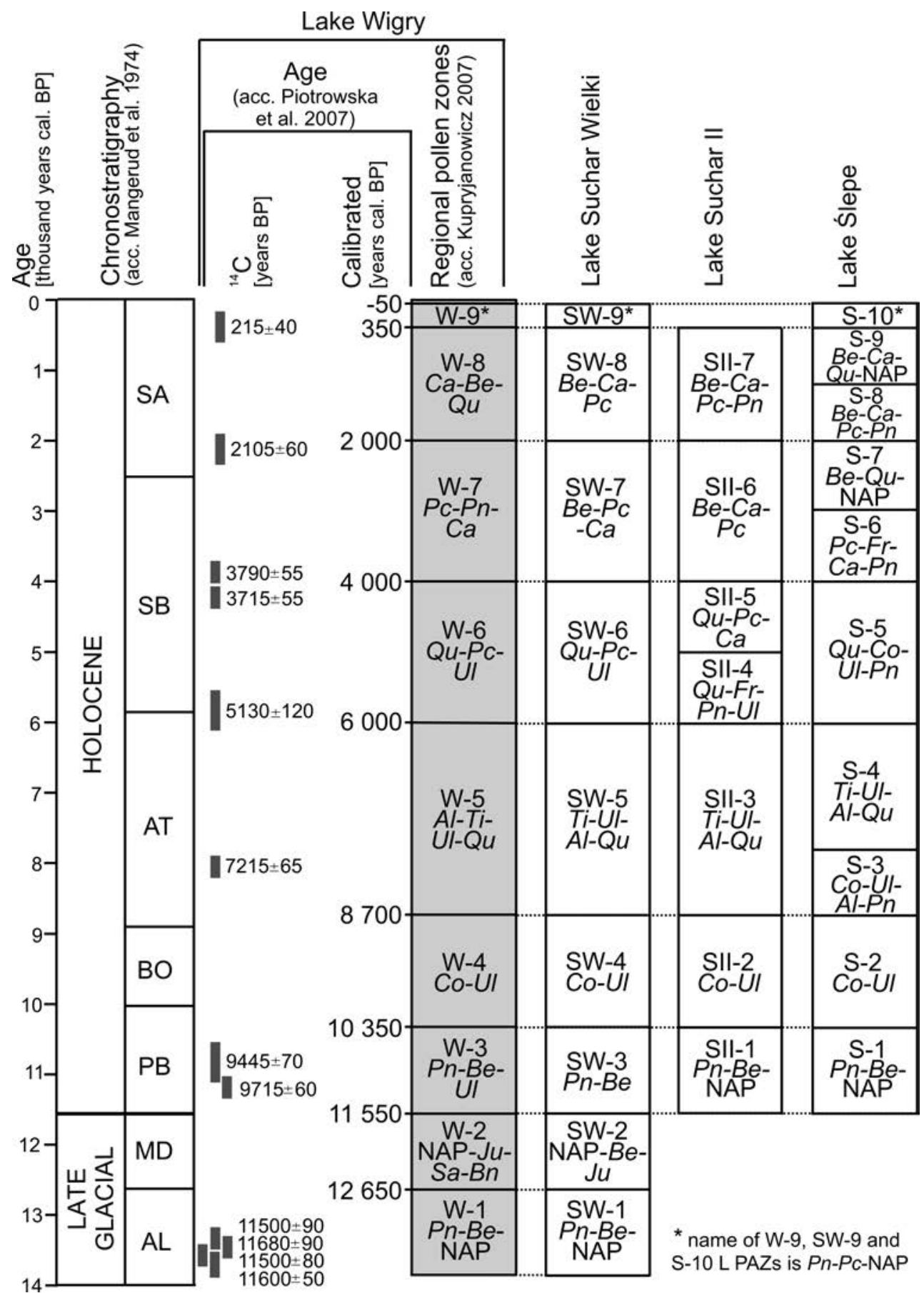

Fig. 2. Correlation of the pollen record from studied lakes and from Lake Wigry.

\section{Pollen analysis}

Samples for pollen analysis were taken every $2 \mathrm{~cm}$. The samples were subject to maceration applying the method of Erdtman's acetolysis (Faegri and Iversen 1975). The preparation of the samples and their microscopic analysis were carried out in accordance with the standard procedure (Berglund and Ralska-Jasiewiczowa 1986).

In each sample, at least 500 sporomorphs were counted. Pollen and spores were identified using several keys (e.g. Moor et al., 1991; Beug 2004). The percentage value of each pollen taxon has been calculated in relation to the total sum of trees and shrubs pollen (AP) and herbaceous plants pollen
(NAP), excluding pollen of local plants, limnophytes and telmatophytes. The results are presented as percentage pollen diagrams prepared with POLPAL 2004 ver. 2011 software (Walanus and Nalepka 1999; Nalepka and Walanus 2003). The diagrams were divided into local pollen assemblage zones (L PAZ) (Figs 3-5) with the use of CONISS (POLPAL) application results.

\section{RESULTS}

The analyzed cores had been shortly described during the field works, and then completed after cleaning them in the laboratory (Tab. 2). 
Table 3

Characterization of the local pollen assemblage zones (L PAZ) distinguished in the analyzed profiles

\begin{tabular}{|c|c|c|}
\hline Symbol and name & Depth $[\mathrm{m}]$ & Description of pollen spectra \\
\hline \multicolumn{3}{|l|}{ Lake Suchar Wielki } \\
\hline $\begin{array}{l}\text { SW-1 } \\
\text { Pinus-Betula-NAP }\end{array}$ & $16.90-16.45$ & $\begin{array}{l}\text { Domination of Pinus sylvestris t. (53-86\%); high values of Betula alba t. (6-33\%), rise of NAP proportion } \\
\text { to } 12 \% \text {; maximum of Salix ( } 2 \%) \text {; still presence of Juniperus communis. }\end{array}$ \\
\hline $\begin{array}{l}\text { SW-2 } \\
\text { NAP-Betula-Juniperus }\end{array}$ & $16.45-15.95$ & $\begin{array}{l}\text { Maximum of NAP (27\%) represented mainly by Artemisia }(8-16 \%) \text {, and Juniperus communis }(8 \%) \text {; in- } \\
\text { crease of Betula alba t. to ca. } 45 \% \text {; depression of Pinus sylvestris t. }(22 \%) \text {; low-percentage culmination of } \\
\text { Picea abies t. }(3 \%) \text { in the top. }\end{array}$ \\
\hline $\begin{array}{l}\text { SW-3 } \\
\text { Pinus-Betula }\end{array}$ & $15.95-14.65$ & $\begin{array}{l}\text { Domination of Pinus sylvestris t. (36-64\%) and Betula alba t. (29-58\%); start of continuous curves of } \\
\text { Ulmus and Corylus avellana and their gradual increase to } 4 \% \text { and } 5 \% \text {, respectively; rather high NAP pro- } \\
\text { portion (3-6\%) and Salix (to 1\%). }\end{array}$ \\
\hline $\begin{array}{l}\text { SW-4 } \\
\text { Corylus-Ulmus }\end{array}$ & $14.65-14.25$ & $\begin{array}{l}\text { Maximum of Corylus avellana (22\%); relatively high proportion of Ulmus (ca. 6\%); rise of Alnus to ca. 6\%; } \\
\text { start of continuous curves of Tilia cordata t., Quercus and Fraxinus excelsior. }\end{array}$ \\
\hline $\begin{array}{l}\text { SW-5 } \\
\text { Tilia-Ulmus-Alnus-Quercus }\end{array}$ & $14.25-11.55$ & $\begin{array}{l}\text { Maximum of Tilia cordata t. (5\%), Ulmus }(9 \%) \text {, Alnus }(22 \%) \text { and Fraxinus excelsior }(4 \%) \text {; systematic in- } \\
\text { crease of Quercus to } 8 \% \text {; Corylus avellana slightly lower than previous zone; still presence of Picea abies } \mathrm{t} \text {. }\end{array}$ \\
\hline $\begin{array}{l}\text { SW-6 } \\
\text { Quercus-Picea-Ulmus }\end{array}$ & $11.55-10.55$ & $\begin{array}{l}\text { Maximum of Quercus (13\%); relatively high values of Fraxinus excelsior (ca. } 3 \% \text { ) and Corylus avellana; } \\
\text { gradual rise of Picea abies t. to } 3 \% \text {; start of Carpinus betulus continuous curve; decrease of Alnus to } 16 \% \text {, } \\
\text { Tilia cordata t. to } 1 \% \text { and Ulmus to } 2 \% \text {. }\end{array}$ \\
\hline $\begin{array}{l}\text { SW-7 } \\
\text { Betula-Picea-Carpinus }\end{array}$ & $10.55-9.45$ & $\begin{array}{l}\text { Significant rise of Betula alba t. (to } 38 \%) \text {; slight increase of Carpinus betulus (to } 3 \%) \text {; relatively high pro- } \\
\text { portion of Corylus avellana (6-12\%), Quercus (4-8\%) and Tilia cordata t. (1-2\%); rise of NAP to } 4 \% \text {. }\end{array}$ \\
\hline $\begin{array}{l}\text { SW-8 } \\
\text { Betula-Carpinus-Picea }\end{array}$ & $9.45-8.25$ & $\begin{array}{l}\text { High percentage of Betula alba t. (28-39\%); relatively high values of Carpinus betulus with two peaks (5\% } \\
\text { and } 6 \% \text { ) as well as Quercus (4-8\%); Corylus avellana lower than previous zone (ca. 3\%); still presence of } \\
\text { Picea abies t. (1-4\%); decrease of Alnus to 8\%; very low proportion of Ulmus, Tilia cordata t. and Fraxinus } \\
\text { excelsior; NAP slightly lower than previous zone. }\end{array}$ \\
\hline $\begin{array}{l}\text { SW-9 } \\
\text { Pinus-Picea-NAP }\end{array}$ & $8.25-7.57$ & $\begin{array}{l}\text { High values of Pinus sylvestris t. (35-48\%) and NAP (4-18\%), including cultivated plants as Cerealia t., } \\
\text { Fagopyrum and Cannabis sativa cf., as well as few human indicators as Rumex acetosella t., Plantago } \\
\text { lanceolata, Artemisia, Poaceae and Chenopodiaceae; relatively high proportion of Picea abies t. (2-5\%); } \\
\text { decline of all other trees and shrubs. }\end{array}$ \\
\hline \multicolumn{3}{|l|}{ Lake Suchar II } \\
\hline $\begin{array}{l}\text { SII-1 } \\
\text { Pinus-Betula-NAP }\end{array}$ & $12.60-11.85$ & $\begin{array}{l}\text { Domination of Pinus sylvestris t. (44-80\%), and next of Betula alba t. (to } 77 \% \text { ); high proportion of NAP } \\
\text { (6-11\%); start of continuous curves of Ulmus, Corylus avellana and Alnus in the top part of the zone; pres- } \\
\text { ence of Corylus avellana, Alnus, Ulmus, Quercus and Tilia cordata t. in the bottom part - probably in sec- } \\
\text { ondary bed. }\end{array}$ \\
\hline $\begin{array}{l}\text { SII-2 } \\
\text { Corylus-Ulmus }\end{array}$ & $11.85-11.35$ & $\begin{array}{l}\text { Maximum of Corylus avellana (25\%); relatively high proportion of Ulmus (ca. 6\%); rise of Alnus from } 2 \% \\
\text { to } 5 \% \text {; start of continuous curves of Tilia cordata t., Quercus, Fraxinus excelsior and Picea abies t. }\end{array}$ \\
\hline $\begin{array}{l}\text { SII-3 } \\
\text { Tilia-Ulmus-Alnus-Quercus }\end{array}$ & $11.35-9.35$ & $\begin{array}{l}\text { Culminations of Tilia cordata t. (2-5\%), Ulmus (5-11\%) and Alnus (to } 24 \%) \text {; systematic rise of Quercus } \\
(1-7 \%) \text { and Fraxinus excelsior (1-5\%); values of Corylus avellana slightly low than previous zone } \\
(10-22 \%) \text {. }\end{array}$ \\
\hline $\begin{array}{l}\text { SII-4 } \\
\text { Quercus-Fraxinus-Pinus-Ul } \\
\text { mus }\end{array}$ & $9.35-8.75$ & $\begin{array}{l}\text { Maximum of Quercus (10\%); relatively high values of Fraxinus excelsior (2-4\%); increase of Pinus } \\
\text { sylvestris t. to ca. } 37 \% \text {; small rise of Picea abies t.; still fairly high values of Corylus avellana (10-15\%); } \\
\text { fall of Tilia cordata t. (to } 2 \% \text { ) and Ulmus (to } 3 \% \text { ). }\end{array}$ \\
\hline $\begin{array}{l}\text { SII-5 } \\
\text { Quercus-Picea-Carpinus }\end{array}$ & $8.75-7.85$ & $\begin{array}{l}\text { Rise of Picea abies t. to ca. 5\%; relatively high proportion of Quercus (ca. 9\%) and Corylus avellana } \\
\text { (6-14\%); start of Carpinus betulus continuous curve; slight increase of Betula alba t. (to 27\%); decrease of } \\
\text { Tilia cordata t. (to 1\%), Ulmus (to 1\%) and Fraxinus excelsior (to 1\%). }\end{array}$ \\
\hline $\begin{array}{l}\text { SII-6 } \\
\text { Betula-Carpinus-Picea }\end{array}$ & $7.85-7.35$ & $\begin{array}{l}\text { Increase of Betula alba t. to } 35 \% \text {, Carpinus betulus to 4\% and NAP to 6\%; relatively high values of Picea } \\
\text { abies t. (to 4\%), Quercus (to } 8 \% \text { ) and Pinus sylvestris t. (to } 31 \% \text { ); proportion of Corylus avellana much } \\
\text { lower than previous zone (5-6\%); fall of Alnus, Ulmus, Tilia cordata t. and Fraxinus excelsior. }\end{array}$ \\
\hline $\begin{array}{l}\text { SII-7 } \\
\text { Betula-Carpinus-Picea-Pin } \\
\text { us }\end{array}$ & $7.35-6.65$ & $\begin{array}{l}\text { Maximum of Carpinus betulus (5\%); increase of Pinus sylvestris t. to ca. } 43 \% \text {; relatively high values of } \\
\text { Picea abies t. (4\%), Betula alba t. (33\%), Quercus (7\%) and NAP (7\%); low-percentage culmination of } \\
\text { Salix; decline of all other trees and shrubs. }\end{array}$ \\
\hline \multicolumn{3}{|l|}{ Lake Ślepe } \\
\hline $\begin{array}{l}\text { S-1 } \\
\text { Pinus-Betula-NAP }\end{array}$ & $5.60-5.35$ & $\begin{array}{l}\text { At first peak of Betula alba t. (45\%), and then Pinus sylvestris t. (53\%); relatively high NAP values (4-8\%); } \\
\text { rising values of Ulmus and Corylus avellana; presence of Salix, Alnus and Quercus. }\end{array}$ \\
\hline $\begin{array}{l}\text { S-2 } \\
\text { Corylus-Ulmus }\end{array}$ & $5.35-5.05$ & $\begin{array}{l}\text { Maximum of Corylus avellana (27\%); high percentages of Betula alba t. (35\%); relatively high proportion } \\
\text { of Ulmus (ca. } 8 \%) \text {; depression of Pinus sylvestris t. }(22-30 \%) \text {; rise of Alnus to } 6 \% \text { and Quercus to } 2 \% \text {; start } \\
\text { Tilia cordata t. continuous pollen curve. }\end{array}$ \\
\hline $\begin{array}{l}\text { S-3 } \\
\text { Corylus-Ulmus-Alnus-Pinus }\end{array}$ & $5.05-4.65$ & $\begin{array}{l}\text { Two peaks of Pinus sylvestris t. (45\% and 40\%); depression of Corylus avellana }(15-21 \%) \text { and Ulmus } \\
(5 \%) ; \text { Betula alba t. lower than previous zone (18-25\%); increase of Alnus to } 20 \% \text {, Tilia cordata t. to } 3 \% \\
\text { and Quercus to } 2 \% \text {. }\end{array}$ \\
\hline $\begin{array}{l}\text { S-4 } \\
\text { Tilia-Ulmus-Alnus-Quercus }\end{array}$ & $4.65-3.55$ & $\begin{array}{l}\text { Maximum of Tilia cordata t. (7\%), Ulmus }(9 \%) \text {, Alnus }(30 \%) \text { and Salix (3\%); increase of Quercus to } 8 \% \\
\text { and Fraxinus excelsior to } 4 \% \text {; Pinus sylvestris t. lower than previous zone (14-29\%); Betula alba t. oscillat- } \\
\text { ing around } 13-30 \% \text {, and Corylus avellana around } 10-19 \% \text {. }\end{array}$ \\
\hline $\begin{array}{l}\text { S-5 } \\
\text { Quercus-Corylus-Ulmus- } \\
\text { Pinus }\end{array}$ & $3.55-3.15$ & $\begin{array}{l}\text { Maximum of Quercus (14\%); two peaks of Corylus avellana }(21 \% \text { and } 18 \%) \text { and Pinus sylvestris t. }(28 \% \\
\text { and } 33 \%) \text {; still quite high values of Ulmus }(2-6 \%) \text {; continuous occurrence of Picea abies t. and Carpinus } \\
\text { betulus; depressions of Tilia cordata t. (1\%) and Fraxinus excelsior }(1 \%) \text {. }\end{array}$ \\
\hline
\end{tabular}


Table 3 continued

\begin{tabular}{|c|c|c|}
\hline Symbol and name & Depth $[\mathrm{m}]$ & Description of pollen spectra \\
\hline \multicolumn{3}{|l|}{ Lake Ślepe } \\
\hline $\begin{array}{l}\text { S-6 } \\
\text { Picea-Fraxinus-Carpinus- } \\
\text { Pinus }\end{array}$ & $3.15-2.65$ & $\begin{array}{l}\text { Culminations of Picea abies t. (4\%), Carpinus betulus (3\%), Fraxinus excelsior ( } 4 \% \text { ) and Pinus sylvestris t. } \\
(37 \%) \text {; depression of Quercus (6\%); fall of Corylus avellana to } 6 \% \text {, Ulmus to } 1 \% \text { and Tilia cordata t. to } 1 \% \text {. }\end{array}$ \\
\hline $\begin{array}{l}\text { S-7 } \\
\text { Betula-Quercus-NAP }\end{array}$ & $2.65-2.25$ & $\begin{array}{l}\text { Rise of Betula alba t. to } 33 \% \text {; small peak of Quercus (10\%); NAP culmination (3-6\%); depressions of Pinus } \\
\text { sylvestris t. (ca. } 26 \%) \text {, Picea abies t. (ca. 1\%) and Carpinus betulus (2\%); decrease of Corylus avellana to } \\
3 \% \text {. }\end{array}$ \\
\hline $\begin{array}{l}\text { S-8 } \\
\text { Betula-Carpinus-Picea- } \\
\text { Pinus }\end{array}$ & $2.25-1.45$ & $\begin{array}{l}\text { Very high proportion of Betula alba t. (26-34\%); relatively high values of Carpinus betulus (3-5\%); culmi- } \\
\text { nation of Pinus sylvestris t. (29-42\%) and Picea abies t. (1-3\%); decline of Alnus, Corylus avellana, Ulmus, } \\
\text { Tilia cordata t. and Fraxinus excelsior; NAP lower than previous zone. }\end{array}$ \\
\hline $\begin{array}{l}\text { S-9 } \\
\text { Betula-Carpinus-Quercus- } \\
\text { NAP }\end{array}$ & $1.45-0.95$ & $\begin{array}{l}\text { Culminations of Betula alba t. (34-41\%), Carpinus betulus }(2-7 \%) \text {, Quercus }(3-9 \%) \text { and Alnus }(10-17 \%) \text {; } \\
\text { meaning increase of NAP (4-20\%), including cultivated plants as Cerealia t., Fagopyrum and Cannabis } \\
\text { sativa cf., as well as few human indicators as Rumex acetosella t., Plantago lanceolata, Artemisia, Poaceae } \\
\text { and Chenopodiaceae; depression of Pinus sylvestris t. (19-30\%); still presence of Salix; very low proportion } \\
\text { of all other trees and shrubs. }\end{array}$ \\
\hline $\begin{array}{l}\text { S-10 } \\
\text { Pinus-Picea-NAP }\end{array}$ & $0.95-0.75$ & $\begin{array}{l}\text { Very high values of NAP (9-18\%); rise of Pinus sylvestris t. to } 49 \% \text { and Picea abies t. to } 3 \% \text {; decline of } \\
\text { Betula alba t. to } 20 \% \text {, Carpinus betulus to } 1 \% \text {, Quercus to } 2 \% \text { and Alnus to } 7 \% \text {; very low percentages of all } \\
\text { other trees and shrubs. }\end{array}$ \\
\hline
\end{tabular}

In the simplified pollen diagrams, 9 local pollen assemblage zones were distinguished for Lake Suchar Wielki (Fig. 3), 7 for Lake Suchar II (Fig. 4) and 10 for Lake Ślepe (Fig. 5). Their short characteristics are showed in Table 3.

\section{DISCUSSION - RECONSTRUCTION OF VEGETATION CHANGES}

\section{Late Glacial}

Allerød interstadial (ca. 13350-12650 cal. years BP according to Ralska-Jasiewiczowa et al., 1999 and Litt et al., 2001) is represented only in pollen profile from Lake Suchar Wielki (SW-1 Pinus-Betula-NAP L PAZ - Fig. 3). The palynological record shows the dominance of the forest with a strong predominance of pine (Pinus sylvestris t. pollen) and the presence of open communities with grasses and other herbs (Artemisia, Chenopodiaceae Apiaceae, Thalictrum, Cichoriaceae) as well as shrub communities of juniper (Juniperus communis), dwarf birch (Betula nana t. pollen) and shrubby willows (pollen of Salix pentandra t., Salix cf. herbacea).

Younger Dryas stadial (ca. 12650-11550 cal. years BP according to Ralska-Jasiewiczowa et al., 1999 and Litt et al., 2001) like the previous period, is represented only in the pollen profile from Lake Suchar Wielki (SW-2 NAP-BetulaJuniperus L PAZ - Fig. 3). The palynological record shows a significant increase in the acreage of open communities (maximum of herbaceous plants in the pollen record), responding to the climate cooling. The maximum spread of mugwort (Artemisia), goosefoot (Chenopodiaceae), and juniper (Juniperus) suggests not only the drop in temperature, but also a significant reduction in moisture (Ralska-Jasiewiczowa et al., 1998). The vegetation was of a mosaic nature with patches of shrubby tundra formed mainly by dwarf birch (Betula nana t. pollen) and shrubby willows (pollen of Salix pentandra t. and Salix undiff.) in wet places and patches of juniper (Juniperus communis) and steppe grasslands in dry habitats.

The pollen of pine (Pinus sylvestris t.) and of woody birch (Betula alba t.), which dominates the pollen spectra, could have come from a long distant transport, although one cannot rule out the presence of small clusters of trees among herbaceous and shrubby vegetation. The continuous pollen curve of Picea abies $\mathrm{t}$. in the upper part of the SW-2 pollen zone may suggest that in the meantime spruce was present in the Wigry region - as its quite heavy pollen grains are not transported over long distances. Pollen data from north-eastern Poland (Gałka et al., 2013) and Lithuania (Stančikaite et al., 2002) confirm that spruce was present at that time in northeastern part of Central Europe. Such an early presence of spruce in this area was most likely associated with the spread of Siberian spruce (Picea obovata) from its glacial refugia located in western Russia (Huntley and Birks 1983; Terhürne-Berson 2005; Latałowa and van der Knapp 2006).

\section{Holocene}

Preboreal chronozone (ca. 11550-10350 cal. years BP according to Mangerud et al., 1974 and Walanus and Nalepka 2010) contained the initial stage of Holocene forest development. It is represented in all analyzed profiles (SW-3 Pinus-Betula L PAZ - Fig. 3, SII-1 Pinus-Betula-NAP L PAZ - Fig. 4, S-1 Pinus-Betula-NAP L PAZ - Fig. 5). The climate warming at the transition between the Late Glacial and the Holocene, have limited the area of open plant communities. This is particularly visible in the decline of Juniperus com munis and herbaceous plants pollen and the significant increase in the percentage of pollen of Pinus sylvestris t. and Betula alba t. pollen. The vegetation that dominated the Wigry region all that time were forest with a predominance of pine and a large share of birch. In the second part of the Preboreal period, from about 11000 cal. years BP, first trees and shrubs with a more demanding climatic conditions, such as elm (Ulmus) and hazel (Corylus avellana), could have reached this area. This is documented by the beginning of the continuous curves of pollen of both taxa.

The most developed pollen record of this period is registered in the profile from Lake Suchar Wielki, in which it is represented by the SW-3 Pinus-Betula pollen zone. There is a significant probability that the middle part of this zone, 


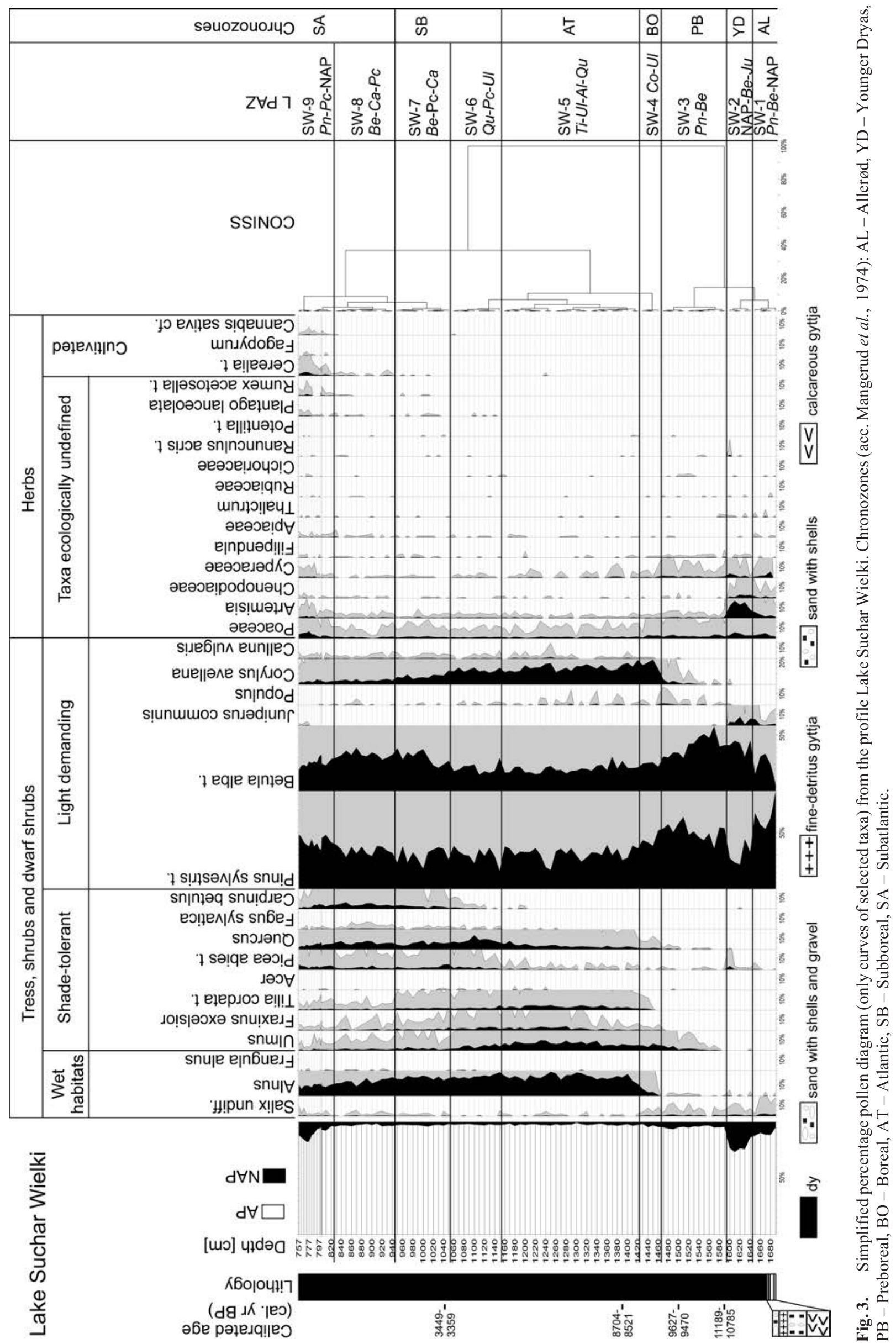




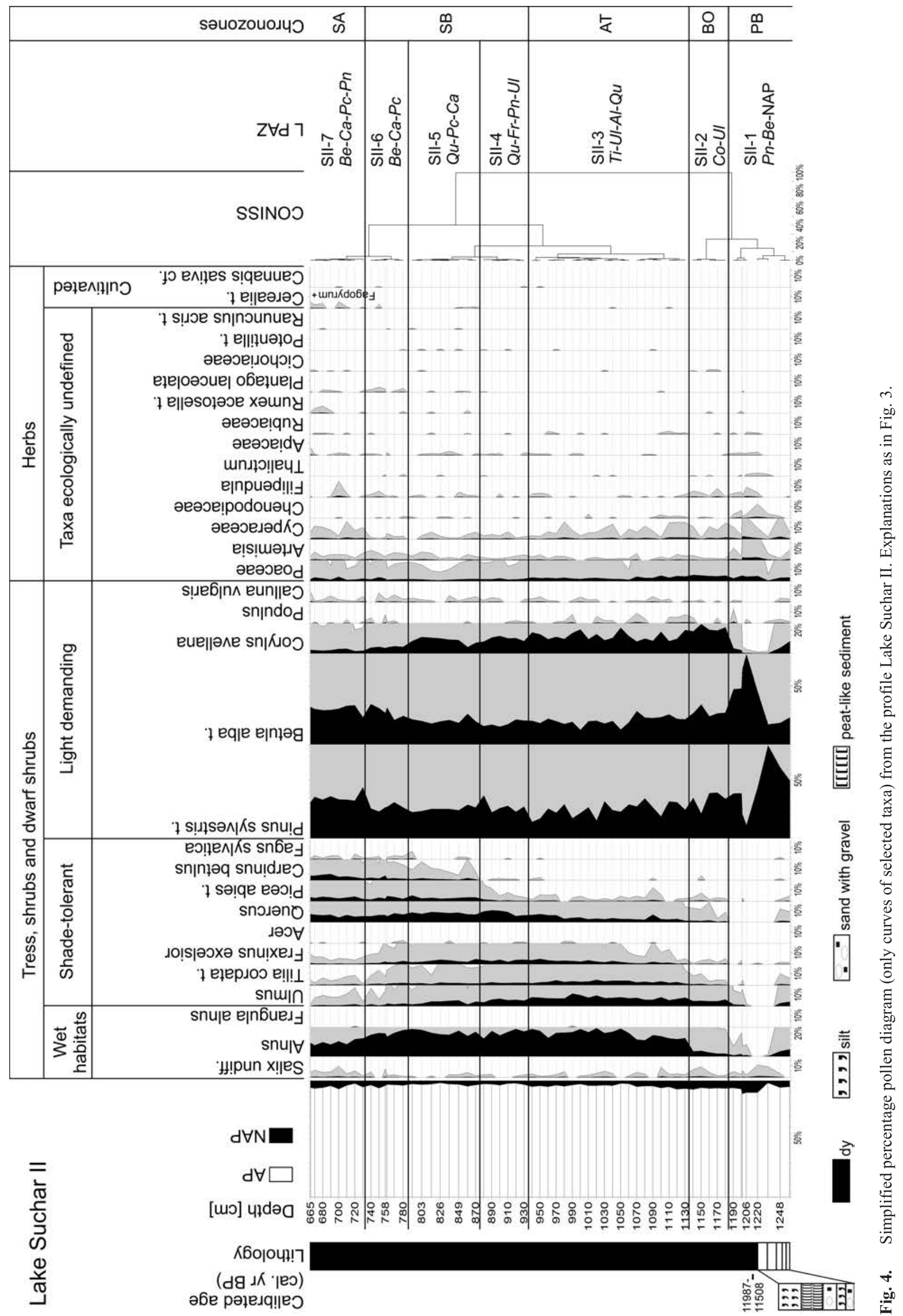




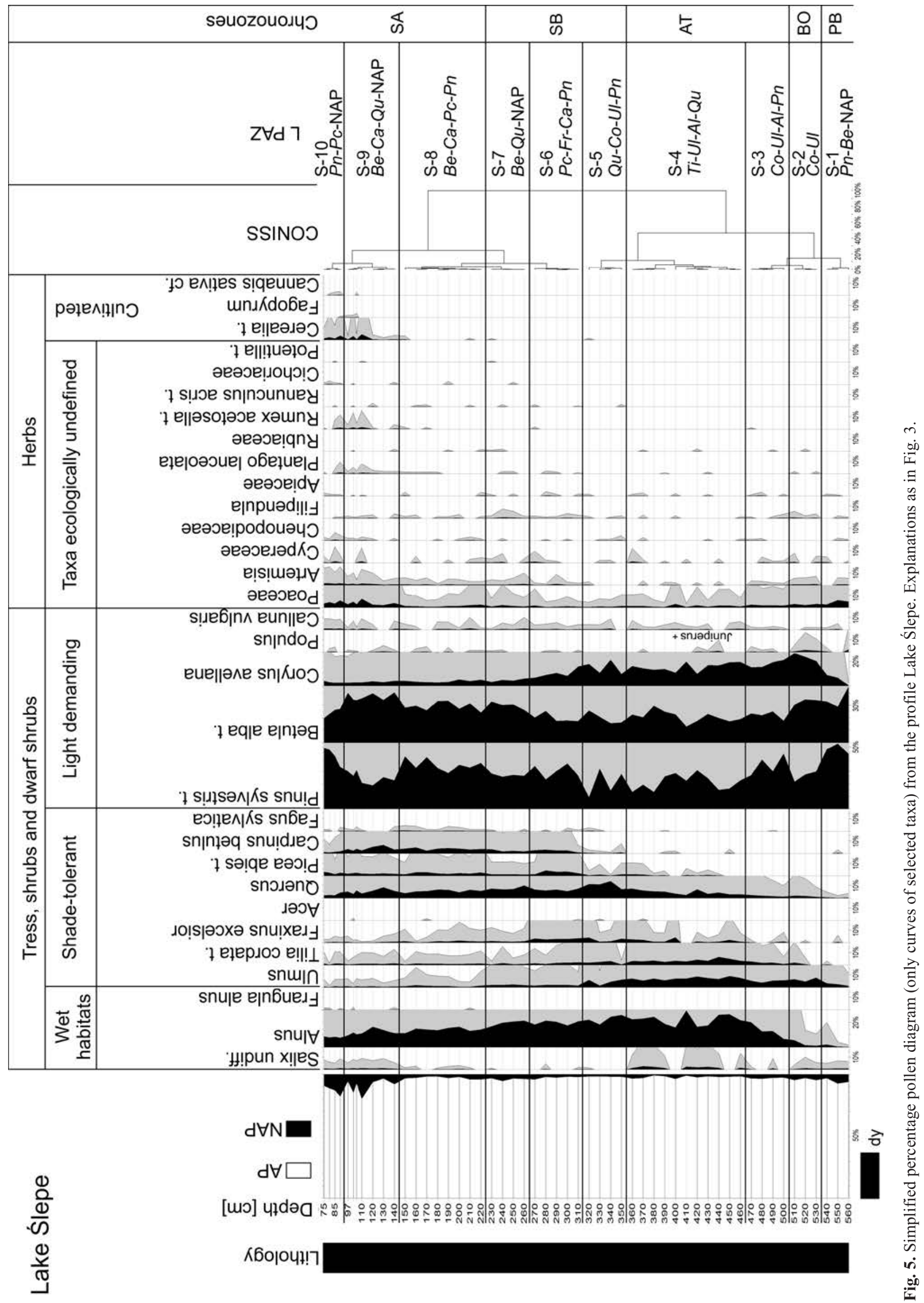


showing the significant spread of birch (ca. $60 \%$ peak of Betula alba t. pollen at the depth of $15.70 \mathrm{~m}$ ) related to the reduction of the importance of pine, may reflect the cool climate oscillation attributable to ca. 11100 cal. years BP. These assumptions are confirmed by radiocarbon date 11189 10785 cal. years BP. Also the peaks of Betula alba t. in the profiles of Lake Suchar II (SII-1 L PAZ, depth of 12.06 m, dated at ca. 11987-11508 cal. years BP - Fig. 4) and Lake Ślepe (S-1 L PAZ, depth of $5.60 \mathrm{~m}$ - Fig. 5), correspond to this first Preboreal cold oscillation.

Quite a high proportion of pollen of mesophilic taxa, mainly Corylus avellana, Ulmus and Alnus, in the bottom section of the Lake Suchar II profile (lower part of the SII-1 L PAZ) representing the older part of the Preboreal period is probably due to a contamination of the core with younger sediments which were "drawn back" during drilling.

Boreal chronozone (ca. 10350-8700 cal. years BP according to Mangerud et al., 1974 and Walanus and Nalepka 2010) is represented in all studied profiles (SW-4 CorylusUlmus L PAZ - Fig. 3, SII-2 Corylus-Ulmus L PAZ - Fig. 4 and S-2 Corylus-Ulmus L PAZ - Fig. 5). The most characteristic feature of the vegetation changes that falls for this part of Holocene is the expansion of hazel respectively documented by an increase in the value of its pollen by over $10 \%$. Hazel arrived in the studied area much sooner, as early as the second part of the Preboreal chronozone, but only in about 10350 cal. years BP did it come to its rapid growth (Huntley and Birks 1983; Miotk-Szpiganowicz et al., 2004). Hazel played a significant role in forest communities, where it is probably formed an undergrowth. The development of hazel contributed to a significant reduction in the role of birch and pine trees, for which the increased shading of the forest floor significantly hindered the renewal process. Wetland habitat gradually began to be overtaken by alder (increase of Alnus pollen). The role of elm steadily grew. Along with the willows, it created riparian forest in the river valleys. At the end of the Boreal chronozone, the first mesophilic deciduous forest with elm (Ulmus), lime (Tilia cordata t. pollen), oak (Quercus) and ash (Fraxinus excelsior) - began to form in the most fertile habitats.

The radiocarbon date from Lake Suchar Wielki, ca. 9627-9470 cal. years BP is likely to have been rejuvenated.

Atlantic chronozone (ca. 8950-5750 cal. years BP according to Mangerud et al., 1974 and Walanus and Nalepka 2010) is represented in all the studied profiles (SW-5 TiliaUlmus-Alnus-Quercus L PAZ - Fig. 3, SII-3 Tilia-UlmusAlnus-Quercus L PAZ - Fig. 4, S-3 Corylus-Ulmus-AlnusPinus and S-4 Tilia-UlmusAlnus-Quercus L PAZ - Fig. 5). This is confirmed by radiocarbon data ca. 8704-8521 cal. years BP obtained from the depths 13.81-13.82 m from Lake Suchar Wielki. Already at the beginning of this period, there was an expansion of alder. It was probably associated with the spread of Alnus glutinosa, which formed alder forest in wet peaty shores of lakes common in the studied area (Szczepanek et al., 2004). Thermophilous trees such as lime, elm and ash, reached at the time the optimum of their Holocene development. In the shady woods the development of hazel was limited due to the less abundant flowering (slight decrease in Corylus avellana pollen). The importance of oak and ash was steadily growing. The increase in the percentage of Picea abies $t$. pollen by over $0.5 \%$ may indicate the presence of single trees of in spruce in the local forest stands (Harmata 1987). However, in palaeoecological reconstructions different pollen values are accepted as evidence for the presence of spruce. Björkmar (1996) assumes that a value around 1\% indicates a local presence of this tree, while Bortenschlager (1970), Markgraf (1980) and Huntley and Birks (1983) suggest that it reflects only by pollen values higher than $5 \%$.

Subboreal (ca. 5750-2650 cal. years BP according to Mangerud et al., 1974 and Walanus and Nalepka 2010) chronozone in the pollen record of the studied profiles is clearly divided into two parts. The older part (ca. 6000-4000 cal. years BP) is represented in all the studied profiles (SW-6 L Quercus-Picea-Ulmus L PAZ - Fig. 3, SII-4 Quercus-Fraxinus-Pinus-Ulmus and SII-5 Quercus-Picea-Carpinus L PAZ - Fig. 4, S-5 Quercus-Corylus-Ulmus-Pinus L PAZ Fig. 5). At this time there was a significant increase in the role of oak in the forest communities of the Wigry region - it reached the maximum of its Holocene spread, which is documented by an increase of Quercus pollen to $10 \%$. The acreage of ash increased as well. The importance of lime and elm decreased, compared to the Atlantic chronozone. Spruce became an increasingly important component of forest. Alder expanded its area significantly in the wetland habitats.

The younger part of the Subboreal chronozone (ca. 4000-2000 cal. years BP) is represented in all studied profiles (SW-7 Betula-Picea-Carpinus L PAZ - Fig. 3, SII-6 Betula-Carpinus-Picea L PAZ - Fig. 4, S-6 Picea-FraxinusCarpinus-Pinus and S-7 Betula-Quercus-NAP L PAZ-Fig. 5). The beginning of this period in the Suwałki region is marked by one of the most important change of the forest in the entire Holocene, which was the expansion of spruce. According to results of palynological research of Lake Wigry, this tree reached in this time the maximum of its Holocene spread in the region (Kupryjanowicz 2007). Its percentage values in the profile from Lake Wigry (about 14\%) are much higher, than the values listed for Picea abies t. at the same time in other sites from the north-eastern Poland (Obidowicz et al., 2004). This is most likely due to the north-eastern direction of migration of spruce in the areas in this part of the country and the climatic conditions of the region, encouraging the development of spruce. In sections of studied profiles, representing the younger part of the Subboreal period, the proportion of Picea abies t. pollen is much lower than in the profile from Lake Wigry - in the profile from Lake Suchar II spruce reaches a maximum of 5\% (SII-6 L PAZ), and in the profiles from Lake Suchar Wielki (SW-7 L PAZ) and Lake Ślepe (Ś-6 L PAZ) only 4\%. This results most likely from the fact that the phase of the maximum spread of spruce lasted a relatively short time (the studies in Lake Wigry shows that was only about 100 years - Kupryjanowicz 2007) and it is possible that the studied profiles do not contain a full-blown pollen record. In Lake Suchar Wielki the spread of spruce was dated at about 3449-3359 cal. years BP.

Starting from ca. 4000 cal. years BP, could have been there a local presence of hornbeam (Carpinus betulus) in the area of the lakes studied, which is indicated by the beginning of a continuous curve of this tree pollen in all profiles containing the record of the younger part of Subboreal chronozone. The values of Carpinus betulus pollen in the sediments 
of the studied lakes at this time are still much lower than in other localities in the north-eastern Poland (Kupryjanowicz 2004, Ralska-Jasiewiczowa et al., 2004). This is probably due to the quite harsh continental climate of the Wigry region, which was not, and is still not, conducive to the development of hornbeam.

Subatlantic chronozone (from ca. 2650 cal. years BP to the present day according to Mangerud et al., 1974 and Walanus and Nalepka 2010) due to the development of vegetation can be divided into two parts. Its older part (ca. 2000-350 cal. years BP) is represented in all profiles (SW-8 Betula-Carpinus-Picea L PAZ - Fig. 3, SII-7 Betula-Carpinus-Picea-Pinus L PAZ - Fig. 4, S-8 Betula-CarpinusPicea-Pinus and S-9 Betula-Carpinus-Quercus-NAP L PAZ - Fig. 5). At this time, when the climate became warmer and wetter, hornbeam and birch increased in importance. There was a slight decrease in the role of spruce compared to the younger part of the Subboreal chronozone. This change, at least in part, may have been caused by anthropogenic factors - as indicated by the presence of many palynological human indicators.

The younger part of the Subatlantic chronozone (from ca. 350 to ca. 50 cal. years BP) was registered only in the profile of Lake Suchar Wielki (SW-9 Pinus-Picea-NAP L PAZ) and the profile of Lake Ślepe (S-10 Pinus-Picea-NAP L PAZ). The pollen data indicate a nearly complete degradation of the majority of trees with higher thermal requirements, such as lime, elm and ash, and the spread of pine. The increased pollen percentages of herbaceous plants, mainly cultivated and related to human activity, when compared to the earlier period, reflect the highest reduction throughout the Holocene of surfaces covered by forest communities and an enlargement of the area of fields, meadows and human settlements. However, the herbaceous plant pollen share is several times lower than in the positions in other parts of Poland, suggesting that anthropogenic impact had never been as strong here as in the central or western Poland (Latałowa 1992, Makohonienko 2000).

Only the profiles from Lake Suchar Wielki (SW-9 Pinus-Picea-NAP L PAZ - Fig. 3) and Lake Ślepe (S-10 Pinus-Picea-NAP L PAZ - Fig. 5) registered the youngest part of the Subatlantic chronozone (ca. 2000-2007 AD), which in the Wigry region was characterized by a weakening of anthropogenic impact and the development of pine forest (Kupryjanowicz 2007). The profile from Lake Suchar II contains no record corresponding to this period, which is due to the fact that with the used equipment it was not possible to retrieve the upper, most hydrated layers of sediments.

\section{SUMMARY AND CONCLUSIONS}

The main phases of the vegetation development in the Wigry National Park during the Late Glacial of the last glaciation and the Holocene were reconstructed.

- Late Glacial is represented only in the sediments of Lake Suchar Wielki. The record of Allerød interstadial shows the dominance of forest with pine and birch and the presence of open communities. During the Younger Dryas stadial the vegetation took the character of a mosaic with patches of shrubby tundra and cold steppe communities.
- The beginning of the Holocene was the time of pine and birch forest development. It had been disturbed in the older part of Preboreal chronozone by a temporary change in vegetation, expressed by an short-lived expansion of birch, which was accompanied by a decrease in the pine importance. It was most likely a reaction to a short-term climate cooling. Due to the lack of precise dating of this phenomenon in the studied pollen profiles, its correlation with Preboreal cold oscillation or Bond's event is purely hypothetical at this moment. This problem requires more extensive discussion at a later stage of the studies.

- The Boreal chronozone was characterized by an expansion of hazel, which reached its Holocene maximum and a gradual overtaking of wetland habitats by alder.

- The Atlantic chronozone was the time of the maximum Holocene development of thermophilous trees such as lime, elm and ash.

- The Subboreal chronozone was the period of the growth of oak combined with an increase of ash in the area and an appearance of hornbeam. Its younger parts were the time of the development of spruce. The expansion of spruce registered in pollen diagram from Wigry expressed by a rapid increase in the share of Picea abies $t$. pollen to $10-15 \%$ in just 100 years is dated on ca. 3972 cal. years BP. Such drastic changes in the composition of forests were due to different causes. Pollen records of investigated lakes in which the share of Picea abies $t$. pollen rapid rose to $5 \%$ and was lower than from Lake Wigry. It indicates that the presence of spruce could be intensified by cold and humid climate was attributable to that part of the Holocene - one of cold climate fluctuations.

- The Subatlantic chronozone was the time of an increased importance of hornbeam and birch, and in its younger part there was a degradation of the majority of trees with larger thermal requirements linked to the spread of pine. Judging by a significant increase in the share of herbaceous plants, which were the so called human indicators, it can be assumed that the causes of these changes were associated with anthropogenic impact.

The pollen record of vegetation changes registered in the profiles of the studied lakes is very similar to that from other sites of the north-eastern Poland (lakes: Wigry, Hańcza, Szurpiły, Linówek) - both in terms of the nature of the recorded changes and their dating. However, on the present stage of research, may be notice that a sudden climate fluctuations known as Bond's events most likely appear in the studied region very clearly, and the large thickness of sediments will allow to precise study of some of them. The discrepancies in the dating of some significant changes in vegetation (e.g. the emergence of spruce) also will require further research, especially those related to a more precise determination of the age of the studied sediments.

\section{Acknowledgements}

M. Fiłoc M.Sc. expresses her gratitude to the Podlaskie Province Marshal's Office, Poland, and WOTT University of Białystok for the scholarship designated for the project "Podlasie Scholarship Fund", Priority of VIII Operation Program Human Capital, funded by the European Social Fund (ESF) and the Polish government, and for the University of Białystok for the research project for young 
scientists Institute of Biology. The research was funded by the Ministry of Science and Higher Education in Poland, project $\mathrm{nr}$ NN305085135 "History of dystrophic lakes of the Wigry National Park in the light of the Holocene succession of their vegetation". Author Magdalena Fiłoc is a beneficiary of the project "Scholarships for PhD students of Podlaskie Voivodeship". The project is co-financed by European Social Fund, Polish Government and Podlaskie Voivodeship.

\section{REFERENCES}

Berglund, B.E., Ralska-Jasiewiczowa, M., 1986. Pollen analysis. In Berglund B.E. (ed.) Handbook of Holocene Palaeoecology and Palaeohydrology, 455-484, John Wiley and Sons, Chichester-New York-Brisbane-Toronto-Singapore.

Beug, H.-J., 2004. Leitfaden der Pollenbestimmung für Mitteleuropa und angrenzende Gebiete. Verlag Dr. Friedrich Pfeil, München.

Björkmar, L., 1996. The Late Holocene history of beech Fagus sylvatica and Norway spruce Picea abies at stand-scale in southern Sweden. Lundqua Thesis 39. Lund University, Department of Quaternary Geology, Lund.

Bortenschlager, S., 1970. Konnte die Fichte die letzte Eiszeit im Ostalpenraum überdauern? Probleme der Weichsel-Spätglazialen Vegetationsentwicklung in Mittel-und Nordeuropa. Voraussetzungen, Vorträge, Diskussionen und Ergebnisse einer internat. pollenanalyt. Arbeitstagung in Frankfurt/Oder (DDR), 28-29.3.

Bronk Ramsey, C., 2009. Bayesian analysis of radiocarbondates. Radiocarbon, 51(1): 337-360.

Drzymulska, D., Kupryjanowicz, M., 2012. Humic lakes of Wigry National Park (NE Poland) - development and expectations for the future. Peatlands International 2, 31-33.

Drzymulska, D., 2012. The Holocene history of dystrophic (humic) lakes of Wigry National Park - a development of water bodies over thousands of years in the light of multi-proxy studies (Jeziora dystroficzne (humusowe) Wigierskiego Parku Narodowego - rozwój zbiorników na przestrzeni tysięcy lat w świetle badań interdyscyplinarnych). Studia Limnologica et Telmatologica 6(2), 111-113 (in Polish).

Drzymulska, D., Kłosowski, S., Pawlikowski, P., Zieliński, P., Jabłońska, E., 2013a. The historical development of vegetation of foreshore mires beside humic lakes; different successional pathways under various environmental conditions. Hydrobiologia 703(1), 15-31.

Drzymulska, D., Zieliński, P., 2013b. Developmental changes in the historical and present-day trophic status of brown water lakes. Are humic water bodies a uniform aquatic ecosystem? Wetlands 33(1), 909-919..

Drzymulska, D., Fiłoc, M., Kupryjanowicz, M., 2013c. Reconstruction of landscape paleohydrology using the sediment archives of three dystrophic lakes in northeastern Poland. Journal of Paleolymnology. DOI: 10.1007/s10933-013- 9754-2.

Faegri, K., Iversen J., 1975. Textbook of pollen analysis. Blackwell Scientific Publications, Copenhagen.

Fiłoc, M., 2013a. Late Glacial and Holocene vegetation changes in the Wigry National Park - preliminary results of palynological studies (Późnoglacjalne i holoceńskie zmiany roślinności Wigierskiego Parku Narodowego - wstępne wyniki badań palinologicznych). In Proniewski M. (ed.) PFS Publikacje naukowe stypendystów, Tom I. Uniwersytet w Białymstoku, Białystok, 21-29 (in Polish).

Fiłoc, M., 2013b. Holocene succession of vegetation in dystrophic Lake Suchar II in the Wigry National Park - preliminary results of pollen analysis (Holoceńska sukcesja roślinności dystroficznego jeziora Suchar II w Wigierskim Parku Narodo- wym - wstępne wyniki analizy pyłkowej). In Proniewski M. (ed.) PFS Publikacje naukowe stypendystów, Tom II. Uniwersytet w Białymstoku, Białystok, 10-20 (in Polish).

Fiłoc, M., Kupryjanowicz, M., 2013a. The changes of vegetation of the Wigierski National Park during the Holocene-preliminary results of studies. In Abstract Book of Conference "IsoG 2013 Environmental geochemistry: methods, trends, questions." Warszawa, 13-15.03.2013, 22-23, Institute of Geological Sciences, Polish Academy of Sciences, Warszawa.

Fiłoc, M., Kupryjanowicz, M., 2013b. Late Glacial and Holocene development of vegetation in the Wigry National Park on the backdrop of climatic changes. In Abstract Book of Conference "Paleoecological reconstructions - lacustrine, peat and cave sediments." 22-24.05.2013 Białka Tatrzańska, 53, Institute of Geological Sciences, Polish Academy of Sciences, Warszawa.

Gałka, M., Tobolski, K., 2013. Macrofossil evidence of early Holocene presence of Picea abies (Norway spruce) in NE Poland. Annales Botanici Fennici 50, 129-141.

Gałka, M., Tobolski, K., Zawisza, E., Goslar, T., 2013. Postglacial history of vegetation, human activity and lake-level changes at Jezioro Linówek in northeast Poland, based on multi-proxy data. Vegetation History and Archaeobotany DOI 10.1007/ s00334-013-0401-7.

Harmata, K., 1987. Late-Glacial and Holocene history of vegetation at Roztoki and Tarnowiec near Jasło (Jasło-Sanok Depression). Acta Palaeobotanica 27, 43-65.

Huntley, B., Birks, H.J.B., 1983. An atlas of past and present pollen maps for Europe: 0- 13000 years ago. Cambridge University Press, Cambridge.

Kondracki, J., 1994. Geography of Poland. Physical-geographical mezoregions (Geografia Polski. Mezoregiony fizycznogeograficzne). PWN, Warszawa (in Polish).

Krzysztofiak, L., Olszewski, K., 1999. Climate of the Wigry National Park (Klimat Wigierskiego Parku Narodowego). X lat Wigierskiego Parku Narodowego, 59-62. Wydawnictwo Włodzimierz Łapiński, Krzywe (in Polish).

Kupryjanowicz, M., 2004. The vegetation changes recorded in sediments of Kładkowe Bagno peat bog in Puszcza Knyszyńska Forest, north-eastern Poland. Acta Palaeobotanica 44(2), 175193.

Kupryjanowicz, M., 2007. Postglacial development of vegetation in the vicinity of the Lake Wigry. Geochronometria 27, 53-66.

Kupryjanowicz, M., 2008. Pelaeoecological research in North-East Poland (Badania palinologiczne w Polsce północno-wschodniej). In Wacnik, A. and Madejska, E., (eds) Polska północnowschodnia w holocenie. Człowiek i jego środowisko. Botanical Guidebooks 30, 77-95 (in Polish with English summary).

Kupryjanowicz, M., Jurochnik, A., 2009. Pollen record of postglacial vegetation changes registered in the sediments of the Wigry Lake (Zapis pyłkowy postglacjalnych zmian roślinności zawarty w osadach dennych jeziora Wigry). In Rutkowski J., Krzysztofiak L. (eds) Jezioro Wigry. Historia jeziora w świetle badań geologicznych i paleoekologicznych, 181-198. Stowarzyszenie "Człowiek i Przyroda", Suwałki (in Polish).

Latałowa, M., 1992. Man and vegetation in the pollen diagrams from Wolin Island (NW Poland). Acta Palaeobotanica 32(1), 123-249.

Latałowa, M., van der Knaap, W.O., 2006. Late Quaternary expansion of Norway spruce Picea abies (L.) Karst. In Europe according to pollen data. Quaternary Science Reviews 25, 27802805.

Lauterbach, S., Brauer, A., Andersen, N., Danielopol, D.L., Dulski, P., Hüls, M., Milecka, K., Namiotko, T., Plessen, B., von Grafenstein, U., DECLAKES Participants 2010. Multi-proxy evidence for early to mid-Holocene environmental and clima- 
tic changes in northeastern Poland. Boreas 40(1), 57-52.

Litt, T., Brauer, A., Goslar, T., Merkt, J., Balaga, K., Müller, H., Ralska-Jasiewiczowa, M., Stebich, M., Negendank, J.F.W., 2001. Correlation and synchronisation of Lateglacial continental sequences in northern central Europe based on annually laminated lacustrine sediments. Quaternary Science Reviews 20, 1233-1249.

Makohonienko, M., 2000. Natural history of Gniezno (Przyrodnicza historia Gniezna). Prace Zakładu Biogeografii i Paleoekologii, Tom 1. Homini, Poznań-Bydgoszcz, 1-148 (in Polish).

Mangerud, U.J., Andersen, S.T., Berglund, B.E., Donner J., 1974. Quaternary stratigraphy of Norden, a proposal for terminology and classification. Boreas 3, 109-128.

Margraf, V., 1980. Pollen dispersal In a mountain area. Grana 19, $127-146$.

Marks, L., 2002. Last Glacial maximum in Poland. Quaternary Science Review 21, 103-110.

Miotk-Szpiganowicz, G., Zachowicz, J., Ralska-Jasiewiczowa, M., Nalepka, D., 2004. Corylus avellana L. - Hazel. In RalskaJasiewiczowa M., Latałowa M., Wasylikowa K., Tobolski K., Madeyska E., Wright H. E. Jr., Turner Ch. (eds) Late Glacial and Holocene history of vegetation in Poland based on iso-p ollen maps, 79-87. W. Szafer Institute of Botany, Polish Academy of Sciences, Kraków.

Moor, P.D., Webb, J.A., Collinson, M.E., 1991. Pollen analysis. Blackwell Scientific Publications.

Nalepka, D., Walanus, A., 2003. Data processing in pollen analysis. Acta Palaeobotanica 43(1), 125-134.

Obidowicz, A., Ralska-Jasiewiczowa, M., Kupryjanowicz, M., Szczepanek, K., Latałowa, M., Nalepka, D., 2004. Picea abies (L.) H. Karst. - Spruce. In Ralska-Jasiewiczowa M., Latałowa M., Wasylikowa K., Tobolski K., Madeyska E., Wright H. E. Jr., Turner Ch. (eds) Late Glacial and Holocene history of vegetation in Poland based on isopollen maps, 147-157, W. Szafer Institute of Botany, Polish Academy of Sciences, Kraków.

Ołtuszewski, W., 1937. History of the Suwałki-Augustów Lakeland forests in the light of the pollen analysis (Historia lasów Pojezierza Suwalsko-Augustowskiego w świetle analizy pyłkowej). Poznańskie Towarzystwo Przyjaciół Nauk, Prace Komisji Matematyczno-Przyrodniczej, B8(4), 1-65 (in Polish with German summary).

OxCal. Available on: https://c14.arch.ox.ac.uk/oxcal/OxCal.html.

POLPAL. Available on: http://adamwalanus.pl/Polpal.html.

Piotrowska, N., Hajdas, I., Bonani, G., 2007. Construction of the calendar timescale for Lake Wigry (Ne Poland) sediments on the basis of radiocarbon dating. Radiocarbon, 49(2), 1133 1143.

Ralska-Jasiewiczowa, M., Geel van, B., Demske, D., 1998. Holocene regional vegetation history recorded in the Lake Gościąż sediments. In Ralska-Jasiewiczowa, M., Goslar, T., Madey- ska, T., Starkel, L., (eds) Lake Gościąż, central Poland. A monographic study, 202-218, W. Szafer Institute of Botany, Polish Academy of Sciences, Kraków.

Ralska-Jasiewiczowa, M., Goslar, T., Bałaga, K., 1999. Biostratygraphy of the Lateglacial in the Lowland of Poland based on the calendar time scale. Terra Nostra, 99/10, 66-71.

Ralska-Jasiewiczowa, M., Latałowa, M., Wasylikowa, K., Tobolski, K., Madeyska, E., Wright, H.E. Jr, Turner, H., 2004. Late Glacial and Holocene history of vegetation in Poland based on isopollen maps. W. Szafer Institute of Botany, Polish Academy of Sciences, Kraków.

Rutkowski, J., Krzysztofiak, L., (ed.) 2009. Lake Wigry. History of the lake in the light of geological and paleoecological researches (Jezioro Wigry. Historia jeziora w świetle badań geologicznych i paleoekologicznych). Stowarzyszenie "Człowiek i Przyroda", Suwałki (in Polish).

Stasiak, J., 1971. Sedimentation rate of the calcareous gytja (Szybkość sedymentacji złóż gytii wapiennej). Zeszyty Problemowe Postępów Nauk Rolniczych 107, 113-119 (in Polish).

Stančikaitè, M., Kabailienè, M., Ostrauskas, T., Guobytė, R., 2002. Environment and man in the vicinity of Lasek Duba and Pelesa, SE Lithuania, during the Late Glacial and Holocene. Geological Quarterly 46(4), 391-409.

Szafer, W., Zarzycki, K., 1977. Szata roślinna Polski. Państwowe Wydawnictwo Naukowe, Warszawa.

Szczepanek, K., Tobolski, K., Nalepka, D., 2004. Alnus Mill. - Alder. In Ralska-Jasiewiczowa, M., Latałowa, M., Wasylikowa, K., Tobolski, K., Madeyska, E., Wright, H. E. Jr., Turner, Ch., (eds) Late Glacial and Holocene history of vegetation in Poland based on isopollen maps, 47-55. W. Szafer Institute of Botany, Polish Academy of Sciences, Kraków.

Terhürne-Berson, R., 2005. Changing distribution patterns of selected conifers in the Quaternary of Europe caused by climatic variations. Dissertation zur Erlangung des Doktorgrades (Dr. rer. nat.) der Mathematisch-Naturwissenschftlichen Fakultät der Rheinischen Friedrich-Wilhelms-Universität, Bonn.

Tylmann, W., Bubak, I., Fiłoc, M., Kupryjanowicz, M., Latałowa, M., Lutyńska, M., Makohonienko, M., Pędziszewska, A., Piortowska, N., Wacnik, A., Witak, M., Zgrundo, A., 2011. Climatic and environmental changes recorded in laminated lake sediments of Northern Poland - TRANSECT-PL. The report on the implementation of own research project (Zapis zmian klimatycznych i środowiskowych w rocznie laminowanych osadach jezior północnej Polski - TRANSECT-PL). Sprawozdanie merytoryczne z realizacji projektu badawczego własnego. Typescript (in Polish).

Walanus, A., Nalepka, D., 1999. POLPAL Program for counting pollen grains, diagrams plotting and numerical analysis. Acta Palaeobotanica, Suppl. 2, 659-661.

Walanus, A., Nalepka, D., 2010. Calibration of Mangerud's boundaries. Radiocarbon 52(4), 1639-1644. 